\title{
An Essential Role for Inhibitor-2 Regulation of Protein Phosphatase-1 in Synaptic Scaling
}

\author{
Benjamin A. Siddoway, ${ }^{1}$ Haider F. Altimimi, ${ }^{2}$ Hailong Hou, ${ }^{1}$ Ronald S. Petralia, ${ }^{3}$ Bo Xu, ${ }^{4}$ David Stellwagen, ${ }^{2}$ \\ and Houhui Xia ${ }^{1}$ \\ ${ }^{1}$ Neuroscience Center, Louisiana State University Health Science Center, New Orleans, Louisiana 70112, ${ }^{2}$ Center for Research in Neuroscience and \\ Department of Neurology and Neurosurgery, McGill University, Montreal, Quebec, Canada H3A 2B4, ${ }^{3}$ National Institute on Deafness and Other \\ Communication Disorders, National Institutes of Health, Bethesda, Maryland 20892-2320, and ${ }^{4}$ Molecular Radiation Biology Laboratory, Southern \\ Research Institute, Birmingham, Alabama 35205
}

Protein phosphatase-1 (PP1) activity is important for many calcium-dependent neuronal functions including Hebbian synaptic plasticity and learning and memory. PP1 activity is necessary for the induction of long-term depression, whereas downregulation of PP1 activity is required for the normal induction of long-term potentiation. However, how PP1 is activated is not clear. Moreover, it is not known whether PP1 plays a role in homeostatic synaptic scaling, another form of synaptic plasticity which functions to reset the neuronal firing rate in response to chronic neuronal activity perturbations. In this study, we found that PP1 inhibitor-2 (I-2) is phosphorylated at serine 43 (S43) in rat and mouse cortical neurons in response to bicuculine application. Expression of I-2 phosphorylation-blocking mutant I-2 (S43A) blocked the dephosphorylation of GluA2 at serine 880, AMPA receptor trafficking, and synaptic downscaling induced by bicuculline application. Our data suggest that the phosphorylation of I-2 at S43 appears to be mediated by L-type calcium channels and calcium/calmodulin-dependent myosin light-chain kinase. Our work thus reveals a novel calcium-induced PP1 activation pathway critical for homeostatic synaptic plasticity.

\section{Introduction}

Protein phosphatase-1 (PP1) is ubiquitously expressed and plays critical roles in many physiological processes, such as mitosis, insulin resistance, and synaptic plasticity (Ceulemans and Bollen, 2004). In neurons, PP1 plays a fundamental role in many calcium-dependent cellular processes, notably Hebbian synaptic plasticity and neuronal cell death. Specifically, PP1 is necessary for the induction and expression of long-term depression (LTD; Mulkey et al., 1993; Morishita et al., 2001; Hu et al., 2006), whereas the downregulation of PP1 activity by an endogenous signaling pathway is required for the induction of long-term potentiation (LTP; Blitzer et al., 1998). Consistent with this, PP1 activity regulates the induction threshold of potentiation versus depression (Jouvenceau et al., 2006). In addition to its function at the synapse, PP1 activation is also required for CREB inactivation in the nucleus, thus limiting the amount of CREB-mediated gene

\footnotetext{
Received Nov. 11, 2012; revised April 29, 2013; accepted May 20, 2013.

Author contributions: H.X. designed research; B.S., H.F.A., H.H., R.S.P., and D.S. performed research; B.X. contributed unpublished reagents/analytic tools; B.S., H.F.A., H.H., R.S.P., D.S., and H.X. analyzed data; B.S., R.S.P., D.S., and H.X. wrote the paper.

This work is supported by NIH R01NS060879, NSF IOS-0824393, NARSAD (2006YI), and LSU REF (Research Enhancement Fund) to H.X., CIHR (Canadian Institute of Health Research) and NSERC (Natural Science and Engineering Research Council) to D.S., NIH (R01ES016354) to B.X., the NIDCD Intramural Research Program to R.S.P., and HSFC (Heart and Stroke Foundation Canada) for H.F.A. We thank Dr. Ya-Xian Wang for help with the immunogold study. We thank Dr. Shyamal Desai for providing founder ATM (+/-) mice used in this study. The authors declare no competing financial interests.

Correspondence should be addressed to Dr. Houhui Xia, Neuroscience Center, Louisiana State University Health Sciences Center, 2020 Gravier Street, Suite D, New Orleans, LA 70112. E-mail: hxia@|suhsc.edu.

DOI:10.1523/JNEUROSCI.5241-12.2013

Copyright $\odot 2013$ the authors $\quad 0270-6474 / 13 / 3311206-06 \$ 15.00 / 0$
}

transcription (Bito et al., 1996). PP1 functions to constrain learning and memory because of its roles in Hebbian synaptic plasticity and CREB-mediated gene transcription (Genoux et al., 2002). The PP1 molecule was hence called a molecule of forgetfulness (Silva and Josselyn, 2002).

Despite the important roles of PP1 in these diverse calciumdependent neuronal functions, how PP1 is activated by calcium is not clear. This is due in part to the fact that PP1 does not bind to calmodulin and is thus not activated by calcium and/or calmodulin directly. The difficulty of studying PP1 lies in the fact that there exist many PP1 regulatory binding proteins $(>100)$, functioning to increase/modify PP1 substrate specificity and/or regulate PP1 enzymatic activity. Each PP1 holoenzyme, formed between the catalytic subunit PP1 and its regulatory binding protein, plays a different function from other PP1 holoenzymes. PP1 pharmacological inhibitors inhibit most of the PP1 holoenzymes as well as other protein phosphatases. Thus, manipulating individual $\mathrm{PP} 1$ regulator proteins will be more informative for studying the role of PP1 in specific cellular process.

One cellular process with a potential role for PP1 is synaptic scaling, or homeostatic synaptic plasticity, a negative feedback response in neurons to reset the neuronal firing rate in response to chronic perturbations of neuronal activity (Turrigiano et al., 1998). Chronic elevation in neuronal firing leads to a reduction of glutamatergic synaptic strength, termed homeostatic synaptic downscaling, which shares with LTD the trafficking of surface AMPARs as an expression mechanism. However, whether PP1 plays a critical role in synaptic downscaling is not known. 
A

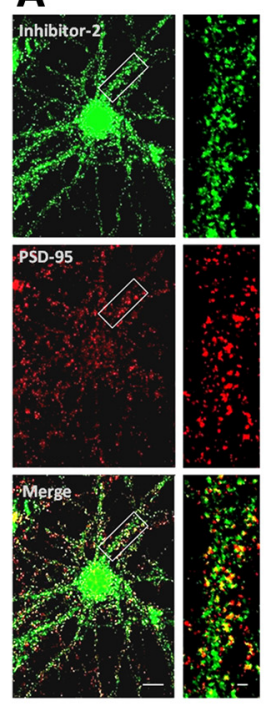

B

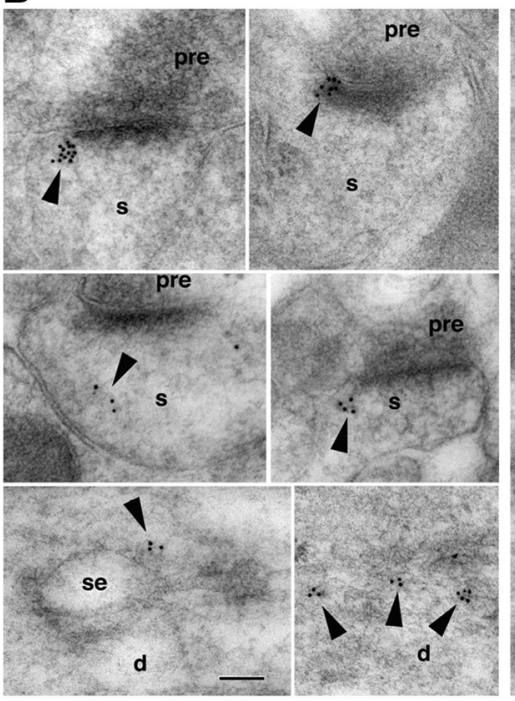

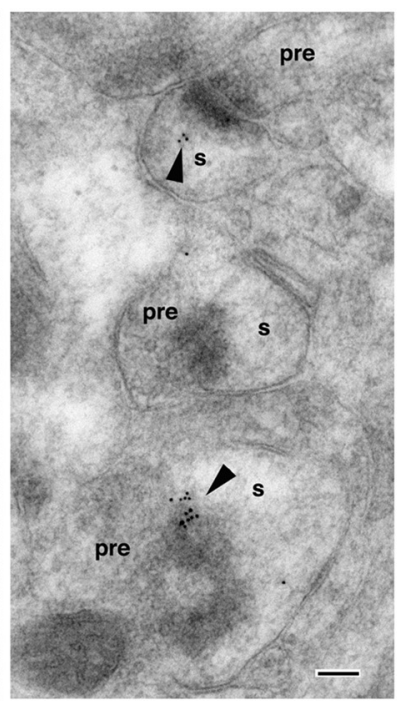

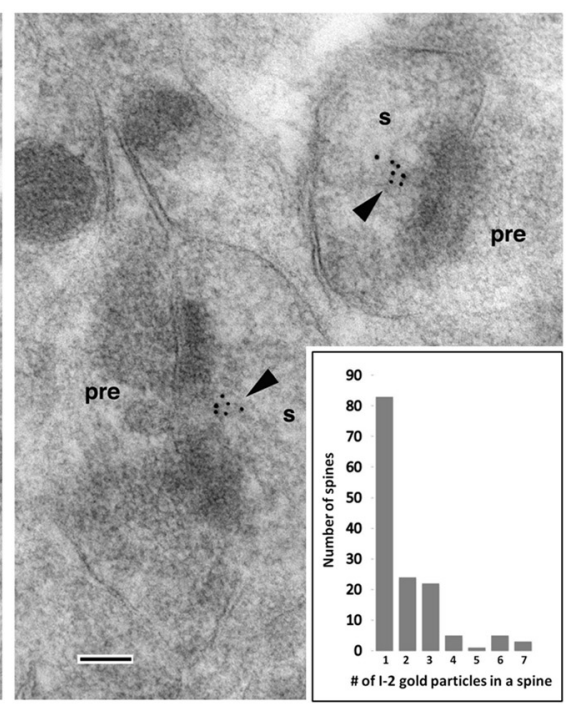

Figure 1. I-2 localizes to dendritic spines in neurons. $\boldsymbol{A}$, Localization of endogenous I-2 (green) and PSD95 (red, a marker for synaptic spines) in primary cortical neurons. Scale bars: 10 and $1 \mu$ m, respectively. $\boldsymbol{B}$, Immunogold localization of I-2 and its quantitation in spines in the hippocampal CA1 stratum radiatum of the P37 rats. Labeling of vesiculate structures (arrowheads) can be seen in postsynaptic spines (s) as well as in dendrites (d). Dendrites show labeling in various tubulovesicular structures including distinctive large sorting endosome (se) complexes (note the typical structure of the swollen vesicle and tubular extension of the main component adjacent to the smaller labeled vesicle). Pre, Presynaptic terminal. Inset, The number of spines containing at least one l-2 gold particle of 413 total spines from two animals (with similar results between animals). Scale bar, $100 \mathrm{~nm}$.

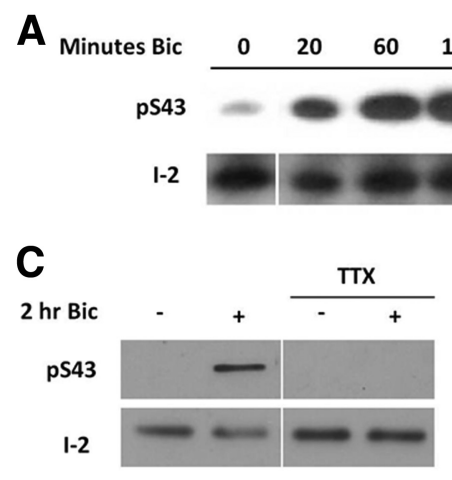

\section{B}
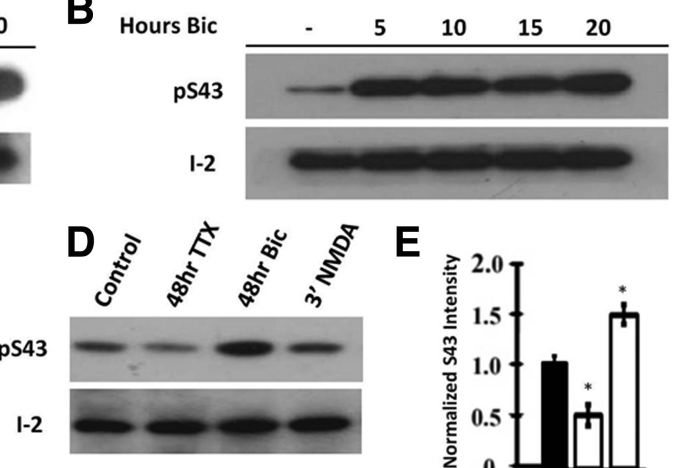

Figure 2. Bidirectional regulation of $\mathrm{I}-2$ phosphorylation at $\$ 43$ by synaptic activity. $A, B$, Time course of $\mathrm{I}-2$ phosphorylation at S43 in primary cortical neurons in response to bicuculline (Bic; $40 \mu \mathrm{M}$ ) application. C, Neurons were pretreated with TTX (2 $\mu \mathrm{M})$ before Bic application. D, E, Western blot showing I-2 phosphorylation at $S 43$ in neurons treated with $\operatorname{TTX}(2 \mu \mathrm{M}, 48 \mathrm{~h})$, Bic $(40 \mu \mathrm{M}$, $48 \mathrm{~h})$, or NMDA (100 $\mu \mathrm{M}, 3 \mathrm{~min})$. Data expressed as means \pm SEM; ${ }^{*} p<0.01$.

PP1 activity is controlled by a number of regulatory proteins, including inhibitor-1 (I-1), inhibitor-2 (I-2), and dopamine- and cAMP-regulated phosphoprotein-32 (DARPP-32). However, the expression level and synaptic localization of both I-1 and DARPP-32 are relatively low in cortical and hippocampal CA1 neurons (Allen et al., 2000; Glausier et al., 2010).

In this report, we found that I- 2 is expressed in both cortical and hippocampal neurons and can localize to vesicular structures at synapses. We show that I-2 is phosphorylated at S43 by elevated neuronal activity. Expression of I-2 (S43A) blocked the bicuculline-induced GluA2 dephosphorylation at $\mathrm{S} 880$, a known PP1 site (Hu et al., 2007; States et al., 2008), suggesting that PP1 is activated by bicuculline application. We found that ataxia telangiectasia mutated (ATM) which has been shown to phosphorylate I-2 at S43 in HEK293 cells, is not the I-2 kinase in cortical neurons. Rather, our data suggest that the calcium/calmodulin
$\mathrm{E}$

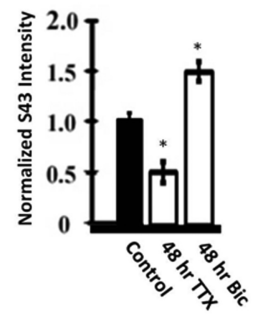

$\left(\mathrm{Ca}^{2+} / \mathrm{CaM}\right)$-dependent protein kinase (MLCK) phosphorylates I-2 at S43. Finally, we demonstrate that the PP1-I-2MLCK pathway activated by L-type calcium channels is essential in homeostatic regulation of glutamatergic synaptic efficacy in cortical neurons.

\section{Materials and Methods}

Primary neuronal cell cultures. Primary cortical neurons were prepared from mixed male/ female E18 Sprague Dawley (SD) rat embryos or P0 mouse pups for wild-type and littermate ATM knock-out mice. Cells were plated at $0.5 \times 10^{6}$ per well $\left(\sim 50,000 / \mathrm{cm}^{2}\right.$ for biochemistry, $\sim 25,000 / \mathrm{cm}^{2}$ for immunostaining) on poly-L-lysine $(50 \mu \mathrm{g} / \mathrm{ml}$ in borate buffer) coated 6 well culture dishes (or on glass coverslips for immunostaining and electrophysiology) in neurobasal medium supplemented with 2\% B27 and 1\% glutamax (Invitrogen). Three- to four-weekold primary neurons were used in all experiments except noted. All experimental protocols for live animals were approved by the Institutional Animal Care and Use Committee of Louisiana State University Health Sciences Center. ATM founder mice were obtained from Dr. Shyamal Desai (Department of Biochemistry, Louisiana State University Health Sciences Center) with the permission of Dr. Peter J. McKinnon (St. Jude Children's Research Hospital, Memphis, TN). ATM KO mouse generation was described by Herzog et al. (1998).

Immunofluorescence. Immunofluorescence was performed exactly as described by Hu et al. (2007), except as noted. Primary antibodies I-2 and PSD95 were used and secondary anti-goat conjugated Alexa Fluor 488 (for I-2), and anti-mouse conjugated Alexa Fluor 568 (for PSD95) were used in this study.

Immunogold electron microscopy. Postembedding immunogold labeling was based on established methods (Petralia et al., 2010; Wu et al., 2011). Controls, lacking the primary antibody, showed only rare gold labeling. 


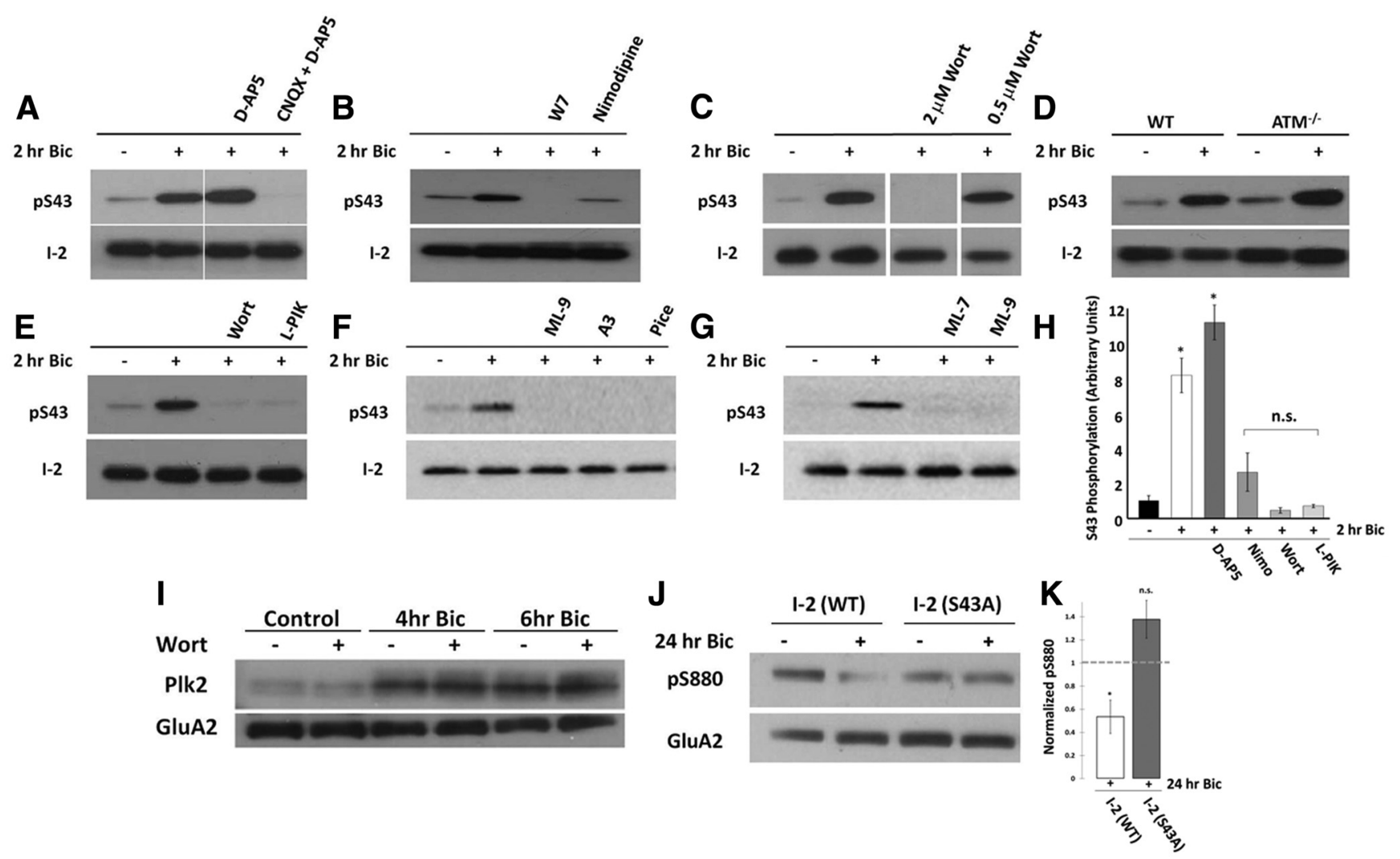

Figure 3. Characterization of PP1 activation via I-2 phosphorylation at $S 43$. I-2 phosphorylation at $S 43$ in primary cortical neurons was determined by Western blotting under a variety of conditions. A, Neurons were pretreated with D-AP5 $(50 \mu \mathrm{m})$ or combination of CNQX $(40 \mu \mathrm{m})$ and D-AP5 $(50 \mu \mathrm{m})$ before Bic application. B, Neurons were pretreated with W7 (25 $\mu \mathrm{M})$ or nimodipine (Nimo; $10 \mu \mathrm{m}$ ) before Bic application. C, Neurons were pretreated with wortmannin (Wort; 0.5 or $2 \mu \mathrm{m}$ ) before Bic application. D, Mouse cortical cultures (WT and ATM ${ }^{-1-}$ ) were treated with Bic. E, Neurons were pretreated with Wort $(2 \mu \mathrm{M})$ or L-PIK $(5 \mu \mathrm{M})$, both are inhibitors of MLCK, before Bic application. $\boldsymbol{F}$, Neurons were pretreated with ML-7 (50 $\mu \mathrm{M}), \mathrm{ML}-9(50 \mu \mathrm{M})$. G, A3 $(100 \mu \mathrm{M})$ or picetannol (Pice; $150 \mu \mathrm{M}$ ) before Bic application. H, Quantitation of normalized I-2 phosphorylation at S43 under different conditions. I, Neurons pretreated with I-2-PP1 signaling inhibitor (Wort; $2 \mu \mathrm{m} ; \boldsymbol{C})$ for 20 min after which Bic $(40 \mu \mathrm{m})$ was added for the time indicated. Plk2 expression was then determined. Total GluA2 served as loading control. Data expressed as means \pm SEM; ${ }^{*} p<$ 0.01. J, Inhibiting PP1 via I-2 (S43A) blocks dephosphorylation of GluA2 at 5880 induced by chronic synaptic activation. $\boldsymbol{K}$, Quantitation of GluA2 phosphorylation at $\$ 880$ under different conditions.

Constructs, transfection, and recombinant viruses. CFP, CFP-I-2 (WT), and CFP-I-2(S43A) was cloned from pECFP-C1 (Clontech) into improved Sindbis viral expression vector of pSinRep5 (nsP2S726) (Kim et al., 2004). Sindbis viruses were prepared as described previously (Hu et al., 2007), except that DH-BB helper was used. Cortical neurons were infected to nearly $100 \%$ for biochemical Western blotting experiments. For electrophysiology recordings, transfection was done by calcium phosphate precipitation method with DNA constructs unknown to the experimenter.

Antibodies. Antibodies were obtained from Thermo-Scientific (PSD95 MAb, mouse), R\&D systems (I-2 PAb, goat), NeuroMab (GluA2 mAb, mouse), and Santa Cruz Biotechnology (B-Tubulin mAb, mouse). The description of rabbit polyclonal I-2 phospho-antibody pS43 can be found in Tang et al. (2008).

Chemicals. Drugs and chemicals were purchased from Tocris Bioscience (TTX, D-AP5, CNQX, nimodipine, wortmannin, NMDA, ML-7, ML-9, and picetannol), Sigma-Fluka (bicuculline and A3), ThermoPierce (sulfo-linked biotin), and Calbiochem (MLCK inhibitory peptide 18 [L-PIK]).

Surface receptor analysis. Surface receptor analysis was performed as previously described (Hu et al., 2010) to determine surface GluAl and GluA2. Briefly, cortical neurons were cooled on ice, washed twice with ice-cold $\mathrm{DPBS}^{2+}$ and then incubated with $1 \mathrm{mg} / \mathrm{ml}$ sulfo-linked biotin for $30 \mathrm{~min}$ at $4^{\circ} \mathrm{C}$. Unreacted sulfo-linked biotin was quenched by washing cells three times with quenching buffer (in mM: 50 Tris- $\mathrm{HCl}, 150$ $\mathrm{NaCl}, 1$ EDTA with protease and phosphatase inhibitors in $\mathrm{DPBS}^{2+}, \mathrm{pH}$ 7.4). Sulfo-linked biotinylation samples were lysed in RIPA buffer where streptavidin-conjugated agarose beads were used to pull down surface proteins.
Electrophysiology. Whole-cell patch-clamp recordings were recorded at DIV 19-22. Pipettes were filled with (in mM): 117 Cs-methylsulfonate, 20 HEPES, 1 EGTA, $0.1 \mathrm{CaCl}_{2}, 5 \mathrm{CsCl}, 2.5 \mathrm{MgATP}, 0.25 \mathrm{Na}_{3} \mathrm{GTP}$, pH 7.4. External solution consisted of (in $\mathrm{mm}$ ): $135 \mathrm{NaCl}, 3.5 \mathrm{KCl}, 2 \mathrm{CaCl} 2,1.3$ $\mathrm{MgCl} 2,10$ HEPES, 20 glucose, supplemented with $200 \mathrm{~nm}$ TTX, $25 \mu \mathrm{M}$ $\mathrm{D}-\mathrm{AP} 5$, and $50 \mu \mathrm{M}$ picrotoxin. mEPSCs were detected using template fitting in Clampfit 10.3 with a $7 \mathrm{pA}$ threshold. Cumulative distributions were made using 40 mEPSCs randomly selected per cell.

\section{Results}

PP1, type one protein phosphatase, was initially defined as those serine/threonine protein phosphatases whose activity can be inhibited by both purified I-1 and I-2 (Cohen, 1989). I-1 does not appear to have a high expression level in hippocampus and cortex (Allen et al., 2000; Glausier et al., 2010); however, I-2 has been reported to be expressed in high levels in both the cortex and the hippocampus by in situ hybridization (Sakagami and Kondo, 1995). We found that I-2 is localized to dendrites and dendritic spines where it partially colocalizes with PSD95 in primary neurons ( $\sim 48 \%$; Fig. $1 A$ ). This is confirmed and extended by I-2 immunogold electron-micrograph (EM) studies in rat brain (Fig. $1 B, C$ ) where I-2 appears to localize to vesicular organelles within synaptic spines and dendrites similar to those observed by EM for known AMPA receptor endocytic trafficking molecules, such as Arc (Wu et al., 2011). I-2 localization in endosome and sorting endosome was identified by morphology as per Wu et al. (2011). The efficiency of our gold-labeling is less than half, so our data that 
A
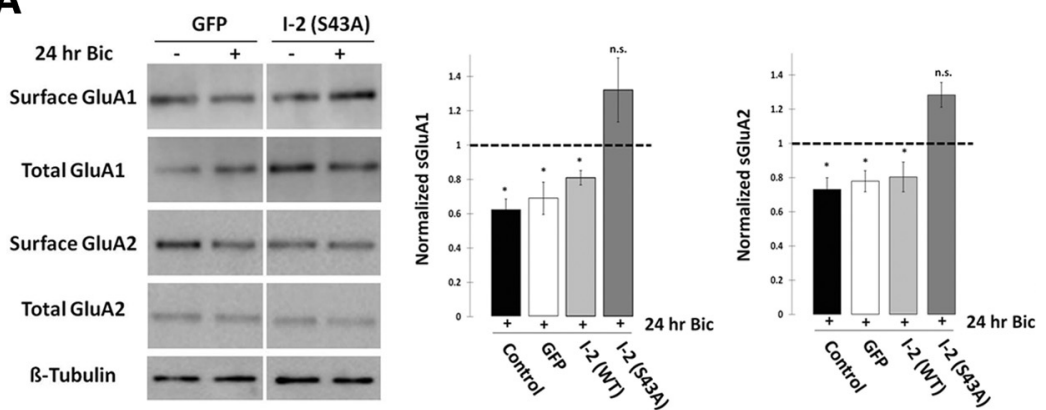

B
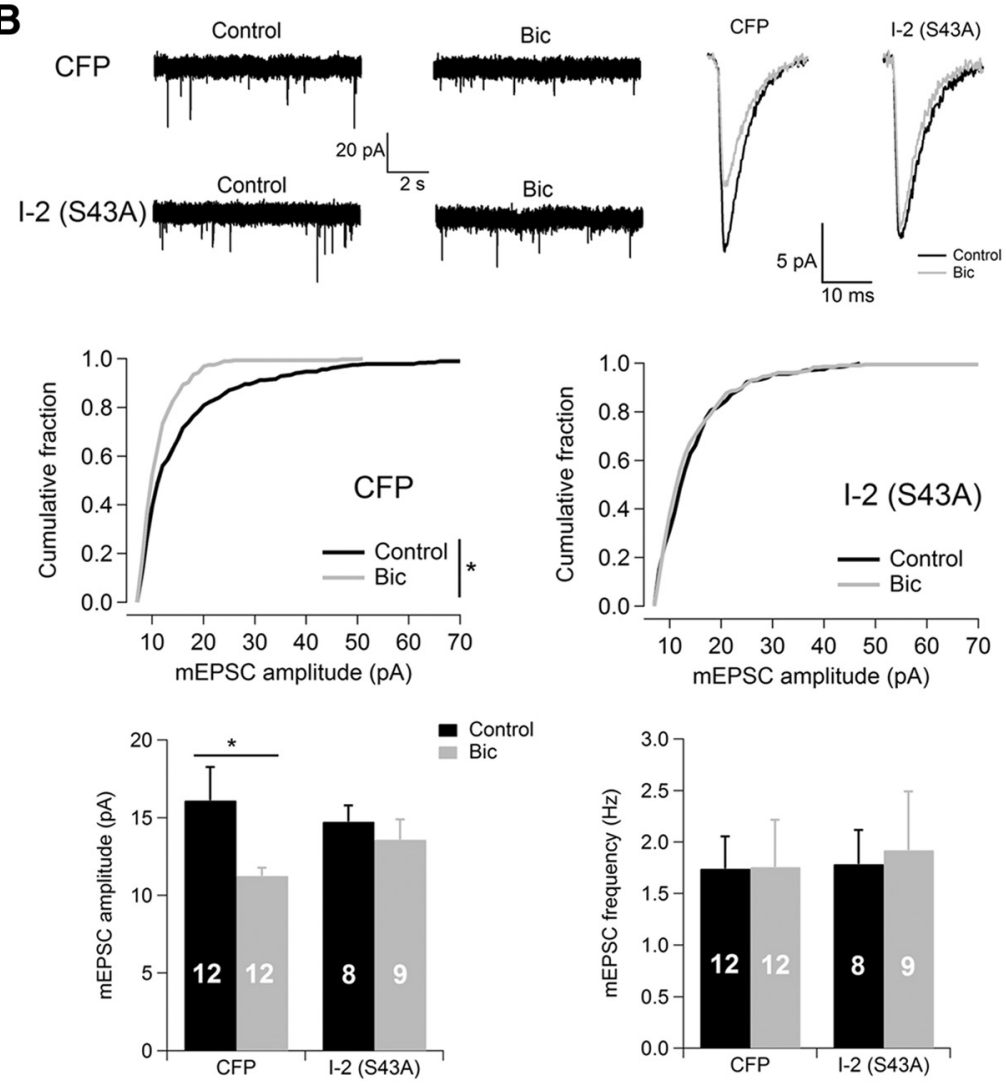

Contro

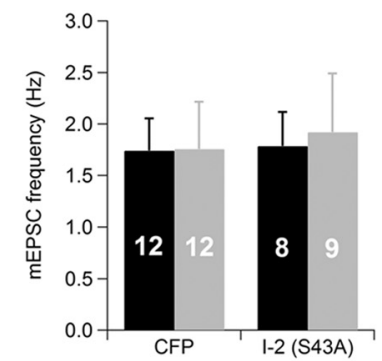

C

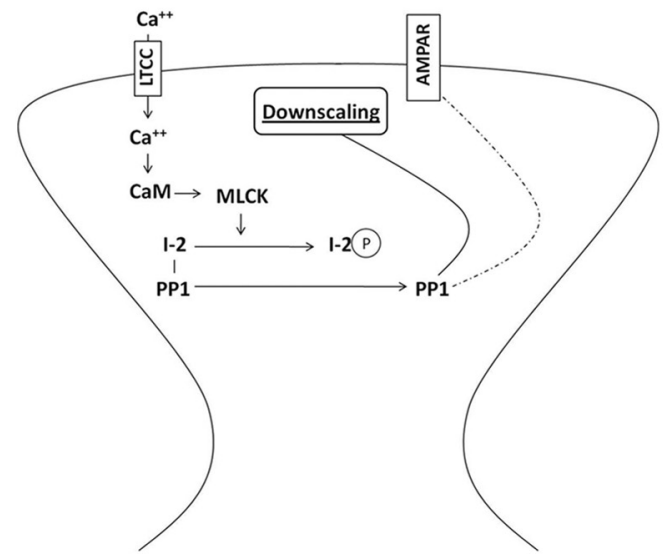

$35 \%$ spines containing I-2 gold particles is an underestimate. The quantitative difference from immunofluorescence study ( $\sim 48 \%$ ) could be due to the age and preparation differences $(\sim$ DIV21 culture vs P37 rats). Nevertheless, the substantial synaptic and endocytic trafficking vesicle localization of I-2 indicates that I-2 may play a regulatory role at glutamatergic synapses.

It has been reported in nonneuronal cells that phosphorylation of I-2 at serine 43 (S43: ${ }^{42} \mathrm{KSQKW}^{46}$ ) leads to PP1 activation via I-2 dissociation from PP1 (Tang et al., 2008). To test whether I-2 S43 phosphorylation is regulated by neuronal activity, we treated the neurons with the $\mathrm{GABA}_{\mathrm{A}}$ receptor antagonist bicuculline to induce robust synaptic activation. In bicuculline-treated neurons, I-2 S43 phosphorylation was increased significantly (Fig. $2 A, B$ ); this was detected by an I-2 phospho-antibody recognizing phosphorylated I-2 at S43 (Tang et al., 2008). The phosphorylation of I-2 at S43 increased dramatically during the first $2 \mathrm{~h}$ of bicuculline application and remained elevated through $48 \mathrm{~h}$ (Fig. $2 A, B$ ). Pretreatment of neurons with TTX eliminated the effect of bicuculline on I-2 phosphorylation at $\mathrm{S} 43$ (Fig. 2C), indicating that the increase of I-2 phosphorylation at S43 is caused by increased neuronal firing.

The phosphorylation of I-2 at S43 is bidirectionally regulated by neuronal activity, as treatment of neurons with TTX alone significantly reduced it (Fig. 2D,E). Moreover, LTD-inducing stimuli such as direct activation of NMDARs with bath NMDA application did not change I-2 phosphorylation at S43 (Fig. 2D). Additionally, pretreatment with D-AP5, an NMDA receptor antagonist, did not block the increase of I-2 phosphorylation at S43 by bicuculline (Fig. $3 A, H$ ). However, pretreatment with D-AP5 and CNQX combination, which blocks neuronal depolarization (Fig. 3A), and pretreatment with nimodipine or W7 (the L-type calcium channel blocker and a calmodulin antagonist, respectively; Fig. $3 B, H$ ), all blocked bicuculline-induced increases in I-2 phosphorylation at S43. These data indicate that the increase of I-2 phosphorylation at S43 requires depolarizationinduced activation of L-type calcium channels and a $\mathrm{Ca}^{2+} / \mathrm{CaM}$-dependent protein kinase.
Figure 4. $\quad-2$ regulated $\mathrm{PP} 1$ activity is critical for synaptic downscaling in response to chronic elevation of neuronal activity. $\boldsymbol{A}$, Inhibiting PP1 via I-2 (S43A) blocks reductions of surface GluA1 and GluA2 expression induced by chronic synaptic activation. Data expressed as means $\pm S E M ;{ }^{*} p<0.01$. B , mEPSCs recorded from neurons transfected with CFP or CFP-I-2 (S43A): sample traces, cumulative distributions of mEPSC amplitudes and frequencies, and summary bar graphs of average mEPSC amplitudes and frequencies (including Ns). Bic ( $40 \mu \mathrm{M}$ ) was added to the medium $24 \mathrm{~h}$ before recording. Data expressed as means \pm SEM, ${ }^{*} p<$ 0.05. C, Model, during elevated synaptic activity calcium enters through L-type calcium channels to activate a calcium/calmodulin- $\leftarrow$

dependent protein kinase, the myosin light-chain kinase, which phosphorylates $1-2$, leading to PP1 activation. The active PP1 may act on any number of substrates including AMPA receptor subunits leading to homeostatic synaptic depression. 
Activity-driven I-2 phosphorylation at $\mathrm{S} 43$ can also be blocked by $2 \mu \mathrm{M}$, but not $0.5 \mu \mathrm{M}$ wortmannin (Fig. $3 C, D, H$ ). Considering the relative $\mathrm{IC}_{50}$ of wortmannin for different enzymes (Nakanishi et al., 1992; Sarkaria et al., 1998) which have a S[N/Q] phosphorylation consensus, only two kinases fit into the wortmannin inhibitory window used in these experiments; ATM and the MLCK family. It has been shown previously that I- 2 is a substrate of ATM in nonneuronal cells (Tang et al., 2008); however, we found that I-2 is still robustly phosphorylated at S43 in response to bicuculline treatment in cultured neurons from ATM knock-out mice (Fig. 3D). On the other hand, incubating neurons with myosin light-chain kinase inhibitory peptide 18 (termed L-PIK), a specific, cell permeable, MLCK family inhibitory peptide that does not target the CaM binding site on MLCK (Lukas et al., 1999), completely abolished the increase of I-2 phosphorylation at $S 43$ (Fig. 3E,H). Consistent with these results, we found that pretreatment of neurons with the MLCK inhibitors ML-7, ML-9, A3, or picetannol all prevented the increase of I-2 phosphorylation at $\mathrm{S} 43$ in response to bicuculline treatment (Fig. $3 F, G)$. These results indicate that MLCK is likely to be the $\mathrm{Ca}^{2+}$ / CaM-dependent protein kinase phosphorylating I-2 at S43.

We observed that bicuculline treatment of neurons decreased the phosphorylation of GluA2 at serine 880 (S880; Fig. 3J,K), a novel observation. This also is suggestive of PP1 activation because GluA2 (S880) is a known PP1 substrate (Hu et al., 2007; States et al., 2008). Expression of an I-2 mutant unable to respond to bicuculline treatment, I-2 (S43A), and thus a constitutive PP1 inhibitor (Tang et al., 2008), significantly attenuated the observed decrease of GluA2 phosphorylation at $\mathrm{S} 880$ (Fig. $3 \mathrm{~J}, \mathrm{~K}$ ). These data demonstrate that I-2 phosphorylation at S43 leads to activation of PP1 which then dephosphorylates GluA2 at S880 in neurons.

Finally, we determined the functional consequence on synaptic transmission of inhibiting the I-2-PP1 pathway. Bicucullineinduced chronic excitation of neurons has been shown to result in synaptic downscaling via a reduction of surface AMPA receptors (O'Brien et al., 1998). In our study, I-2-PP1 signaling is activated over a prolonged time scale by bicuculline treatment and not through acute chemLTD stimuli, and thus we hypothesized that it plays a critical role in homeostatic AMPA receptor trafficking. As expected, prolonged synaptic activation via bicuculline treatment downscaled the number of surface AMPA receptors (Fig. 4A). Consistent with (Jakawich et al., 2010), downscaling required chronic activity manipulation as $5 \mathrm{~h} \mathrm{BIC}$ application was insufficient to alter mEPSCs (Ctrl: $13.4 \pm 1.1 \mathrm{pA}, n=9$; 5 h BIC: $13.2 \pm 1.4 \mathrm{pA}, n=7$; $p=0.92)$. However, expression of an I-2 mutant I-2 (S43A) was sufficient to block this reduction in surface AMPARs, whereas neurons transfected with wild-type I-2 still exhibited downscaling of surface AMPARs (Fig. 4A). To demonstrate that these changes were synaptic, we recorded mEPSCs from neurons expressing I-2. We found that expression of CFP-I-2 (S43A), but not CFP alone, was sufficient to block the bicuculline-induced downscaling of mEPSC amplitude (Fig. 4B).

\section{Discussion}

We have presented two novel findings in this study (Fig. 4C). (1) We have characterized a previously unknown neuronal PP1 activation signaling pathway, mediated through endogenous PP1 I-2 phosphorylation by a $\mathrm{Ca}^{2+} / \mathrm{CaM}$-dependent protein kinase, and (2) we have shown that I-2-PP1 signaling plays a critical role in homeostatic downscaling, a form of synaptic plasticity necessary for the normal function of neurons during elevated activity.

Despite the importance of PP1 in many calcium-dependent neuronal functions, knowledge about PP1 activation mecha- nisms is very limited. The standard, but speculative, model for PP1 activation in hippocampal CA1 neurons proposed that $\mathrm{Ca}^{2+}$ activation of PP2B, via NMDA receptor channel opening, dephosphorylates inhibitor-1 (I-1) to activate PP1 via I-1 disinhibition (Mulkey et al., 1994). However, PP2B-independent PP1 activation has been reported in CA3-CA1 synapses (Morishita et al., 2005) as well as in hippocampal neurons (Chung et al., 2009). Moreover, no CA1 synaptic plasticity phenotypes were observed in I-1 knock-out mice (Allen et al., 2000).

This lack of understanding of the mechanism of PP1 activation is surprising given the important roles that PP1 plays in many forms of synaptic plasticity as well as in memory retention. Our study presented here has characterized an NMDARindependent mechanism of PP1 activation by the chronic elevation of neuronal firing. Our data suggest that opening of L-type calcium channels can mediate a calcium-dependent signaling pathway activating $\mathrm{PP} 1$ via phosphorylation of I-2 at S43, with MLCK the likely $\mathrm{Ca}^{2+} / \mathrm{CaM}$-dependent protein kinase. Our work thus represents a major step in understanding the signaling pathways activating PP1 in response to calcium signals in neurons. I-2 may be a critical regulator of PP1 for different forms of synaptic plasticity, although at least acute LTD stimuli seem unlikely to alter I-2 phosphorylation at S43. However, I-2-PP1 activity is also regulated by phosphorylation at T72 (Cohen, 1989; Li et al., 2006). Future work will determine how PP1 is differentially activated in different forms of synaptic plasticity.

The second novel finding from our current work is the elucidation of the role of PP1 activation through I-2 in homeostatic synaptic downscaling. As a relatively new form of synaptic plasticity, synaptic scaling has received much attention lately. It has been reported that gene expression plays a critical role in homeostatic synaptic depression through the immediate early genes Plk2 and Homerla as well as CaMKK-CaMKIV and MeCP2 proteins (Pak and Sheng, 2003; Seeburg et al., 2008; Goold and Nicoll, 2010; Hu et al., 2010; Qiu et al., 2012; Zhong et al., 2012). However, bicuculline-induced expression of Plk2 remains unchanged in the presence of inhibitors of I-2-PP1 signaling (Fig. $3 I$ ). More work is needed to determine whether I-2-PP1 signaling is involved in nuclear events, regulating the expression of other genes.

Synaptic downscaling takes longer than several hours to develop. Interestingly, robust I-2 phosphorylation at S43 was observed at $2 \mathrm{~h}$ of stimulation, and this may indicate that I-2-PP1 signaling is essential to the early or initiation stage of synaptic plasticity. It is possible that the I-2-PP1 signaling pathway functions to gate synaptic depression, which may then require a combination of many different signals. Although not mutually exclusive, it is also possible that I-2-PP1, based on the I-2 vesicular localization pattern from EM studies, regulates intracellular trafficking to control surface AMPA receptor levels necessary for synaptic downscaling (Fu et al., 2011). Along these lines, the exact role of GluA2 dephosphorylation at S880 in synaptic downscaling will be an important direction for future research.

In summary, we have characterized a previously unknown PP1 regulatory pathway activated in response to calcium in neurons. This MLCK-I-2-PP1 signaling represents a new and interesting future direction both for investigations into neuronal PP1 signaling as well as glutamatergic synaptic plasticity and AMPAR trafficking mechanisms. 


\section{References}

Allen PB, Hvalby O, Jensen V, Errington ML, Ramsay M, Chaudhry FA, Bliss TV, Storm-Mathisen J, Morris RG, Andersen P, Greengard P (2000) Protein phosphatase-1 regulation in the induction of long-term potentiation: heterogeneous molecular mechanisms. J Neurosci 20:3537-3543. Medline

Bito H, Deisseroth K, Tsien RW (1996) CREB phosphorylation and dephosphorylation: a $\mathrm{Ca}^{2+}$ and stimulus duration-dependent switch for hippocampal gene expression. Cell 87:1203-1214. CrossRef Medline

Blitzer RD, Connor JH, Brown GP, Wong T, Shenolikar S, Iyengar R, Landau EM (1998) Gating of CaMKII by cAMP-regulated protein phosphatase activity during LTP. Science 280:1940-1942. CrossRef Medline

Ceulemans H, Bollen M (2004) Functional diversity of protein phosphatase-1, a cellular economizer and reset button. Physiol Rev 84:1-39. CrossRef Medline

Chung HJ, Qian X, Ehlers M, Jan YN, Jan LY (2009) Neuronal activity regulates phosphorylation-dependent surface delivery of G-proteinactivated inwardly rectifying potassium channels. Proc Natl Acad Sci U S A 106:629-634. CrossRef Medline

Cohen P (1989) The structure and regulation of protein phosphatases. Annu Rev Biochem 58:453-508. CrossRef Medline

Fu AK, Hung KW, Fu WY, Shen C, Chen Y, Xia J, Lai KO, Ip NY (2011) APC(Cdh1) mediates EphA4-dependent downregulation of AMPA receptors in homeostatic plasticity. Nat Neurosci 14:181-189. CrossRef Medline

Genoux D, Haditsch U, Knobloch M, Michalon A, Storm D, Mansuy IM (2002) Protein phosphatase 1 is a molecular constraint on learning and memory. Nature 418:970-975. CrossRef Medline

Glausier JR, Maddox M, Hemmings HC Jr, Nairn AC, Greengard P, Muly EC (2010) Localization of dopamine- and cAMP-regulated phosphoprotein-32 and inhibitor-1 in area 9 of Macaca mulatta prefrontal cortex. Neuroscience 167:428-438. CrossRef Medline

Goold CP, Nicoll RA (2010) Single-cell optogenetic excitation drives homeostatic synaptic depression. Neuron 68:512-528. CrossRef Medline

Herzog KH, Chong MJ, Kapsetaki M, Morgan JI, McKinnon PJ (1998) Requirement for ATM in ionizing radiation-induced cell death in the developing central nervous system. Science 280:1089-1091. CrossRef Medline

Hu JH, Park JM, Park S, Xiao B, Dehoff MH, Kim S, Hayashi T, Schwarz MK, Huganir RL, Seeburg PH, Linden DJ, Worley PF (2010) Homeostatic scaling requires group I mGluR activation mediated by Homer $1 \mathrm{a}$. Neuron 68:1128-1142. CrossRef Medline

Hu XD, Huang Q, Roadcap DW, Shenolikar SS, Xia H (2006) Actinassociated neurabin-protein phosphatase-1 complex regulates hippocampal plasticity. J Neurochem 98:1841-1851. CrossRef Medline

Hu XD, Huang Q, Yang X, Xia H (2007) Differential regulation of AMPA receptor trafficking by neurabin-targeted synaptic protein phosphatase-1 in synaptic transmission and long-term depression in hippocampus. J Neurosci 27:4674-4686. CrossRef Medline

Jakawich SK, Neely RM, Djakovic SN, Patrick GN, Sutton MA (2010) An essential postsynaptic role for the ubiquitin proteasome system in slow homeostatic synaptic plasticity in cultured hippocampal neurons. Neuroscience 171:1016-1031. CrossRef Medline

Jouvenceau A, Hédou G, Potier B, Kollen M, Dutar P, Mansuy IM (2006) Partial inhibition of PP1 alters bidirectional synaptic plasticity in the hippocampus. Eur J Neurosci 24:564-572. CrossRef Medline

Kim J, Dittgen T, Nimmerjahn A, Waters J, Pawlak V, Helmchen F, Schlesinger S, Seeburg PH, Osten P (2004) Sindbis vector SINrep (nsP2S726): a tool for rapid heterologous expression with attenuated cytotoxicity in neurons. J Neurosci Methods 133:81-90. CrossRef Medline

Li M, Stefansson B, Wang W, Schaefer EM, Brautigan DL (2006) Phosphorylation of the pro-X-thr-pro site in phosphatase inhibitor-2 by cyclin- dependent protein kinase during M-phase of the cell cycle. Cell Signal 18:1318-1326. CrossRef Medline

Lukas TJ, Mirzoeva S, Slomczynska U, Watterson DM (1999) Identification of novel classes of protein kinase inhibitors using combinatorial peptide chemistry based on functional genomics knowledge. J Med Chem 42: 910-919. CrossRef Medline

Morishita W, Connor JH, Xia H, Quinlan EM, Shenolikar S, Malenka RC (2001) Regulation of synaptic strength by protein phosphatase 1. Neuron 32:1133-1148. CrossRef Medline

Morishita W, Marie H, Malenka RC (2005) Distinct triggering and expression mechanisms underlie LTD of AMPA and NMDA synaptic responses. Nat Neurosci 8:1043-1050. CrossRef Medline

Mulkey RM, Herron CE, Malenka RC (1993) An essential role for protein phosphatases in hippocampal long-term depression. Science 261:1051-1055. CrossRef Medline

Mulkey RM, Endo S, Shenolikar S, Malenka RC (1994) Involvement of a calcineurin/inhibitor-1 phosphatase cascade in hippocampal long-term depression. Nature 369:486-488. CrossRef Medline

Nakanishi S, Kakita S, Takahashi I, Kawahara K, Tsukuda E, Sano T, Yamada K, Yoshida M, Kase H, Matsuda Y (1992) Wortmannin, a microbial product inhibitor of myosin light chain kinase. J Biol Chem 267:2157-2163. Medline

O’Brien RJ, Kamboj S, Ehlers MD, Rosen KR, Fischbach GD, Huganir RL (1998) Activity-dependent modulation of synaptic AMPA receptor accumulation. Neuron 21:1067-1078. CrossRef Medline

Pak DT, Sheng M (2003) Targeted protein degradation and synapse remodeling by an inducible protein kinase. Science 302:1368-1373. CrossRef Medline

Petralia RS, Wang YX, Hua F, Yi Z, Zhou A, Ge L, Stephenson FA, Wenthold RJ (2010) Organization of NMDA receptors at extrasynaptic locations. Neuroscience 167:68-87. CrossRef Medline

Qiu Z, Sylwestrak EL, Lieberman DN, Zhang Y, Liu XY, Ghosh A (2012) The Rett syndrome protein $\mathrm{MeCP} 2$ regulates synaptic scaling. J Neurosci 32: 989-994. CrossRef Medline

Sakagami H, Kondo H (1995) Molecular cloning of the cDNA for rat phosphatase inhibitor-2 and its wide gene expression in the central nervous system. J Chem Neuroanat 8:259-266. CrossRef Medline

Sarkaria JN, Tibbetts RS, Busby EC, Kennedy AP, Hill DE, Abraham RT (1998) Inhibition of phosphoinositide 3-kinase related kinases by the radiosensitizing agent wortmannin. Cancer Res 58:4375-4382. Medline

Seeburg DP, Feliu-Mojer M, Gaiottino J, Pak DT, Sheng M (2008) Critical role of CDK5 and polo-like kinase 2 in homeostatic synaptic plasticity during elevated activity. Neuron 58:571-583. CrossRef Medline

Silva AJ, Josselyn SA (2002) The molecules of forgetfulness. Nature 418: 929-930. CrossRef Medline

States BA, Khatri L, Ziff EB (2008) Stable synaptic retention of serine-880phosphorylated GluR2 in hippocampal neurons. Mol Cell Neurosci 38: 189-202. CrossRef Medline

Tang X, Hui ZG, Cui XL, Garg R, Kastan MB, Xu B (2008) A novel ATMdependent pathway regulates protein phosphatase 1 in response to DNA damage. Mol Cell Biol 28:2559-2566. CrossRef Medline

Turrigiano GG, Leslie KR, Desai NS, Rutherford LC, Nelson SB (1998) Activity-dependent scaling of quantal amplitude in neocortical neurons. Nature 391:892-896. CrossRef Medline

Wu J, Petralia RS, Kurushima H, Patel H, Jung MY, Volk L, Chowdhury S, Shepherd JD, Dehoff M, Li Y, Kuhl D, Huganir RL, Price DL, Scannevin R, Troncoso JC, Wong PC, Worley PF (2011) Arc/Arg3.1 regulates an endosomal pathway essential for activity-dependent beta-amyloid generation. Cell 147:615-628. CrossRef Medline

Zhong X, Li H, Chang Q (2012) MeCP2 phosphorylation is required for modulating synaptic scaling through mGluR5. J Neurosci 32:1284112847. CrossRef Medline 